\title{
Nature of Dadon and Its Effect on Livelihood Status of Two Fishing Communities in Kishoreganj Haor of Bangladesh
}

\author{
A. K. M. Nowsad Alam, Md. Khaled Rahman*, M. U. M. Abu Zakaria, Al-Shahriar, Fanindra Chan- \\ dra Sarker
}

Department of Fisheries Technology, Faculty of Fisheries, Bangladesh Agricultural University, Mymensingh-2202, Bangladesh.

\begin{abstract}
How to cite this paper: A. K. M. Nowsad Alam, Md. Khaled Rahman, M. U. M. Abu Zakaria, Al-Shahriar, Fanindra Chandra Sarker. (2021) Nature of Dadon and Its Effect on Livelihood Status of Two Fishing Communities in Kishoreganj Haor of Bangladesh. International Journal of the Science of Food and Agriculture, 5(1), 140-151.

DOI: 10.26855/ijfsa.2021.03.018

Received: January 25, 2021

Accepted: February 26, 2021

Published: March 10, 2021

*Corresponding author: Md. Khaled Rahman, Department of Fisheries Technology, Faculty of Fisheries, Bangladesh Agricultural University, Mymensingh-2202, Bangladesh.

Email: mkrnion222@gmail.com
\end{abstract}

\begin{abstract}
To assess the nature and effect of dadon (a non-institutional financing way, built upon a verbal contract between the fishers and the money lenders/mohajons, which is paid back by harvested fish at predetermined lower price, along with $5-10 \%$ cash interest) on livelihood status of two fishing communities in Kishoreganj haor, a 12-month study was conducted among the 6 fish landing centers (FLC) under 5 haor upazilas of Kishoreganj district of Bangladesh, viz., Chamra Ghat Matshaya Arat of Karimganj Upazila, Chouganga Matshaya Arat of Itna Upazila, Tarail Matshaya Arat of Tarail Upazila, Korgaon bazar Matshaya Arat of Kotiadi upazila, Nikli Notun Bazar Matshaya Arat and Rodar Podda Matshaya Arat of Nikli Upazila, from August 2018 to July 2019. One hundred twenty interviewees, of which 60 fishermen from dadon receiver (DR) and 60 from dadon non-receiver (DnR), were randomly selected from 6 landing centers by using pre-tested questionnaire interview and focus group discussion to collect empirical data. Results revealed that, about 50\% fishermen received dadon, of which $42 \%$ took dadon from aratder, $4 \%$ from mahajon and 4\% from the relatives or friends. The rate of commission in arat was comparatively lower than the other credit sources. The commission rate taken by aratdar was higher in DR (5.9-8.5\%) compared to DnR (3.9-5.69\%). In addition, about 2.81\%-3.6\% and $1.69 \%-3 \%$ extra commission was taken from DR and DnR, respectively by the people of aratdar during auction of fish. Results revealed that dadon was taken for both fishing purposes $(56.83 \%)$ and household purposes $(43.17 \%)$ and most of the dadon (58\%) was repaid by the beginning of next fishing season. There was no difference of commission observed due to species, size and quality of fish between DR and DnR fishermen. Monthly income and annual savings were comparatively higher in DR fishermen than DnR fishermen. Educational status was comparatively better in DR fishermen than DnR fishermen $(\mathrm{p}<0.05)$. Total land and homestead area, electricity, kitchen and sanitation facilities, as well as home condition were comparatively better in DR fishermen compared to DnR fishermen $(\mathrm{p}<0.05)$. On the other hand, livelihood improvement status, as perceived by the fishermen, was better in DnR compared to DR fishermen $(p<0.05)$. Mobility and ability to make small purchase of women were comparatively better in DnR household than DR $(\mathrm{p}<0.05)$. However, in terms of family decision making for children education, treatment and marriage and economic security, the women from DR fishermen were better empowered. Overall, the DR fishermen were found to led comparative better life than DnR fishermen.
\end{abstract}

\section{Keywords}

Dadon, fishermen, livelihood, social well-being, women empowerment, Kishoreganj haor 


\section{Introduction}

The term "dadon" comes from the Persian word means "to give", and then developed into a technical term for loans as working capital in Bengal [1]. In the last half of the $17^{\text {th }}$ century, most products were secured by the dadon system for long distance trade, and the onward demand for products along with the extent of European trade primarily led to the augmentation of dadon. By the end of the $18^{\text {th }}$ century and the beginning of the $19^{\text {th }}$, the British East India Company had excluded the dadon system from most divisions of export trade [2, 3].

In Bangladesh, presently the sources of rural credit can be classified into two groups. One is a formal or institutional source largely encompassed of banks and NGOs. The other source is generally called informal or non-institutional loans as dadon, mostly taken from aratders, mohajons, money lenders, friends/relatives, traders, land-owners, etc. [4].

In rural areas, fishermen have limited access to the formal or institutional credit system (i.e., banks or NGOs) due to scarce collateral and mortgage properties, like landed or household property. However, fishermen in haor areas are largely dependent on informal credit systems, like the dadon (interest-based loan) system. Dadon is a non-institutional bankrolling way, build upon a verbal agreement between the fishermen and the rich and influential people like money lender or aratdars (called dadondar). Aratdars/money lenders are at the core of the financial system of the fish market in haor areas, in that they finance both backward and forward linkages. By taking a loan, the dadan receivers are bound to sell their harvested fish to aratdar/money lender, who profits in the form of a commission (i.e. about 5\% to $10 \%$ from fresh fish, and $2 \%$ from dried fish) when selling to the third one [5, 6]. At the same instance, the aratdars/money lenders take risks, as the credit receivers can make financial losses, or "disappear" altogether.

Money lending system in rural area (dadon) and a related oppressive patron-client relationship is deeply entrenched in haor fishing areas. Non-government microcredit organizations (NGOs) usually do not consider fishers eligible for micro-credit advances as per need for fishing operations, because fishing as a profession is full of risk and uncertainty. Fishers have very limited access to government commercial or specialized banks as they fail to satisfy the requirements for a mortgage and an extra 'speed money' (bribe) required for a loan. The moneylenders, despite their exploitative roles, operate within the vacuum of socio-cultural, economic and political spaces. The amount of loans varied from a few thousand to several lac taka; interest rates against loan varied from 3-5\% per auction at arat (compared to $15 \%$ in the commercial banks) in haor areas. Poor fishers exhaust themselves in paying interest. In return, fishers get social security from the money lenders. Hindu fishers usually receive 'dadon' from the same-caste money lenders if the amount is small, but the Hindu boat owners (who are again money lenders within their community) consider it safe to receive 'dadon' from the Muslim aratdars, whom they consider as 'powerful persons', with a view to protect their fishing assets and to get 'social security' in the event of communal violence.

Fishers are the principal stakeholder in the fisheries sector. During fishing season, fishers need money for preparations, net mending, the maintenance of boats and engines, as well as for subsistence [5]. Money is given off trust rather than by written document or for collateral property. This relationship between dadondar and dadon receiver, means proper and timely marketing and payments for his products (even though the predetermined lower price). In addition, fishers suffer from great threat due to various reasons. Fishers have fewer fishing rights in depleted stock, having no right of selling their capture in paikers or retail fish markets directly. Moreover, the brutal clutch of money lending by the dadonders/ aratders, the fishers have been less-paid in the primary commission market in many ways such as by high rate of commission, reduced weight—dholon and "big one" taken by the aratders or adatders' staff (koyal, sarker, cleaner etc.) [7].

Most of the dadon loans have been repaid by the beginning of next fishing season in haor region. But not all dadon loans are collected or repaid. As with other forms of tied financial relationships, some of the loans are left out throughout the successive years. This may happen if the money-lending trader wishes to keep the subordinate under his obligation for the next season. Alternatively, it may reflect either the inability of the subordinate trader to repay the loan or the willingness of the money-lending trader to fund some of the other activities of the subordinate [8]. Therefore, this study was developed with an aim (1) to find out the nature of dadon as well as interest on catch, size and quality of captured fish in Kishoreganj haor; (2) to explore the effect of dadon on socio-economic condition of two fishing communities (dadon receiver and dadon non-receiver fishermen) in Kishoreganj haor.

Haors are seasonal floodplains where most of the lands except homestead lands, remain under water for about 6 months. Haor water is rich with aquatic biodiversity since the water is clean and it supports natural breeding of many popular capture fishery species. The main livelihood of poor haor dwellers are fishing from these seasonal waters, as well as, from the rivers around which make networks in such low-lying areas. It was, therefore, assumed that dadon might play an important role on the livelihood of the fishing communities by impacting on fish catch size, catch composition and quality. 


\section{Materials and Methods}

From the survey, nature of dadon, daily life and life style, woman's participation in family, physical assets of fishermen, etc. were generated. To collect primary data, survey was conducted at 6 fish landing centers in 5 haor upazilas of Kishoreganj. These are Chamra Ghat Matshaya Arat in Karimganj upazila (24²8'48.6"N, 9057'18.0"E), Tarail Matshaya Arat in Tarail upazila (24³2'51.7"N, 90³3'36.3"E), Chouganga Matshaya Arat in Itna upazila, $\left(2^{\circ} 31^{\prime} 30.2^{\prime \prime} \mathrm{N}\right.$, 9057'14.9"E), Korgaon Bazar Matshaya Arat in Kotiadi upazila (24¹8'45.9"N, 9054'43.8"E), Rodar Podda Matshaya Arat $\left(24^{\circ} 18^{\prime} 39.8^{\prime \prime} \mathrm{N}, 90^{\circ} 54^{\prime} 58.1^{\prime \prime E}\right)$ and Nikli Notun Bazar Matshaya Arat in Nikli upazila $\left(24^{\circ} 19^{\prime} 55.66 " \mathrm{~N}\right.$, 9056'18.0"E) (Figure 1). The field study was carried out from August, 2018 to July, 2019, while the respondents available at the time of the survey were interviewed. The main target population of this study was the two types of fishermen "dadon receiver (DR) and dadon non-receiver (DnR)". A total of 120 individuals were interviewed (60 interviewees in each group) using a semi-structured questionnaire. Additionally, one focus group discussion and 3 key informant interviews were also conducted with knowledgeable persons, including Upazila Fisheries Officers, local leaders and non-governmental organization (NGO) officials working with fishing communities in each fish landing center.

All data generated in field were put, coded, and filtered in Microsoft Excel ${ }^{\circledR}$ version 2016 software. From the excel sheet, data were further exported and analyzed using SPSS 20 software. The analysis was done using descriptive statistics like percentage, frequency distribution, mean, and standard deviation where necessary. A comparison of proportions and means across the intervention groups was carried out using the appropriate statistical tests including t-test at $5 \%$ significant level $(\mathrm{p}<0.05)$.

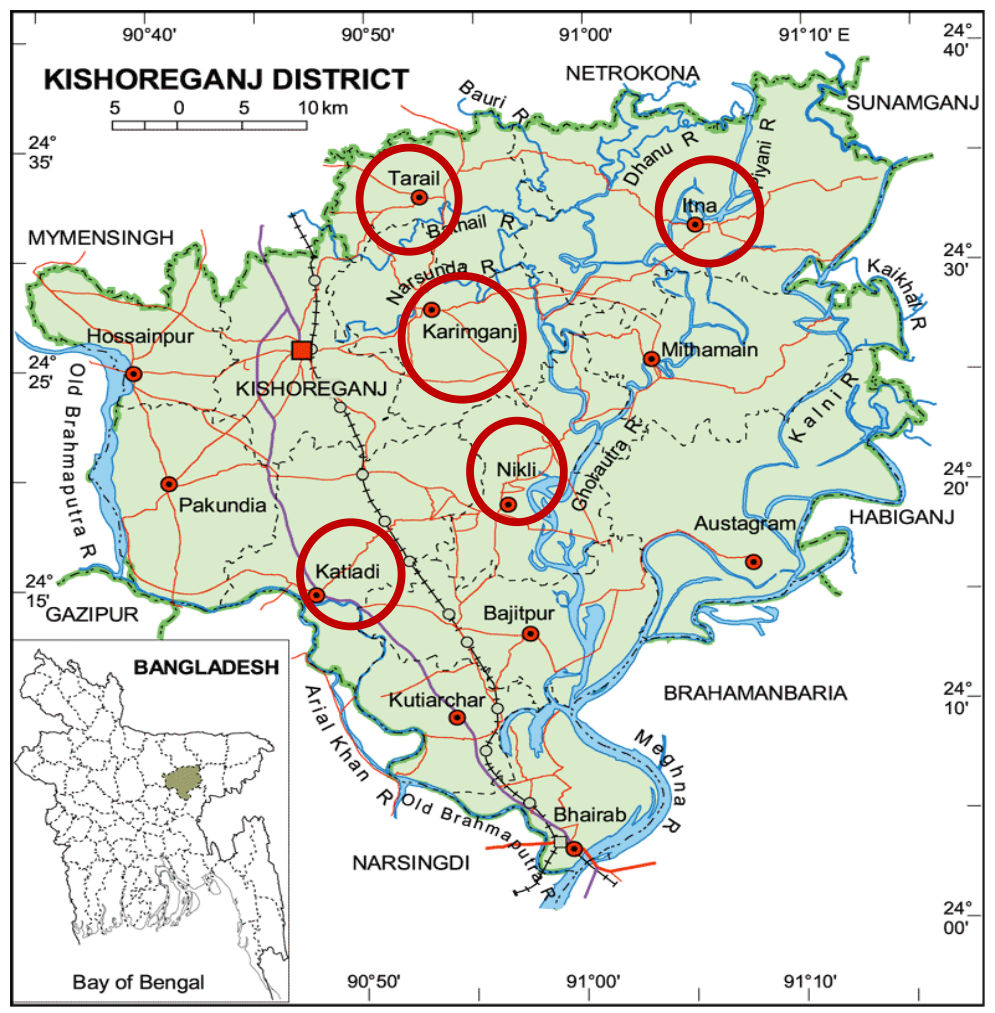

Figure 1. Map showing the location of the study area.

\section{Results and Discussions}

\subsection{Nature of dadon}

The present study revealed that majority of the fisherman (82\%) took loan and/or dadon from different sources, of which non-institutional credit sources provided the highest amount of loan or dadon (50\%) than the institutional credit sources (32\%) in Kishoreganj haor (Figure 2a). The result of the present study showed lesser trends of receiving dadon by the haor fishers compared to high-value species catching fishers, as observed by Islam et al. [9] in hilsa shad (Tenualosa ilisha) sanctuaries in Bangladesh, where dadon receiver were $90 \%$ and also by Chowdhury [10] in hilsa fishing communities in Lakshmipur district, where dadon receiver were $70 \%$. In the haor, $42 \%$ fishermen took dadon from aratders where they bound to sell their fish round the year, while the mahajon provided on $4 \%$ loan (Figure 2b). Khair [11] reported that $40 \%$ of fishermen were found to be dependent on dadondar which agrees with the present result. 
About 27\% and 5\% fishermen took loan from NGOs and banks which were categorized as institutional credit source. About 18\% fishermen did not take loan or dadon from any sources (Figure 2b).

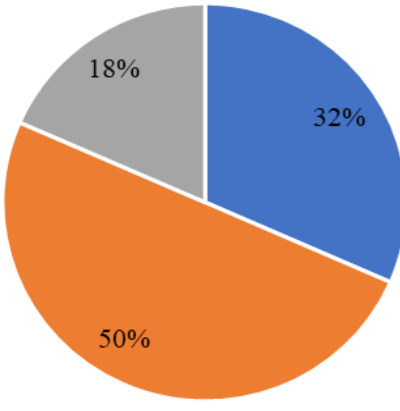

- Institutional source

* Non-institutional source

- Own

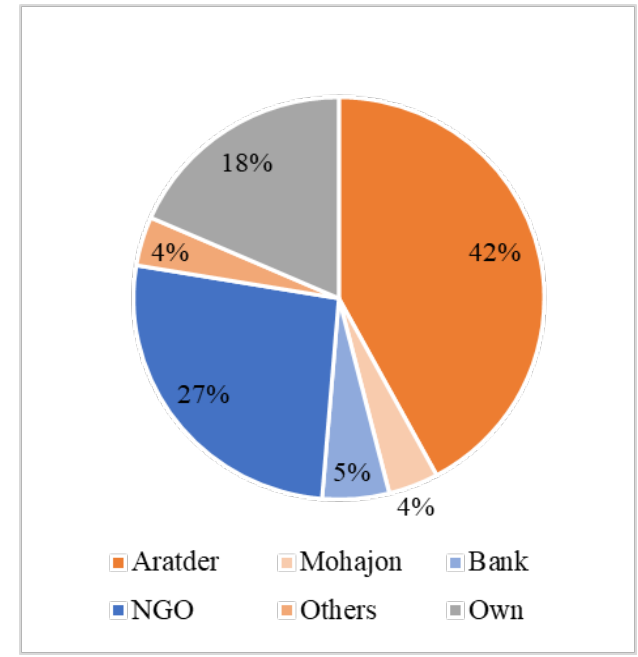

Figure 2. Sources of credit access (\%)

\subsection{Rate of commission against dadon and loan of credit agencies}

The rate of commission of different credit sources are summarized in Figure 3. It was found from the survey that rate of commission in arat was comparatively lower (6.33\%) than the other credit agencies viz. bank (12\%), NGOs (15\%) and mahajon (21.67\%). The Krishi bank took 8\% commission against loan from fishermen which was lower than BRAC bank (14.25\%) and Grameen bank (14\%). The rate of commission in BRAC NGO was $16.29 \%$ followed by Asha (14.48\%) and Dustho Shastho Karzakram (DSK) (14\%). Results also revealed that relatives or friends of dadon receiver fishermen took $4 \%$ commission from them against dadon. These results showed similarities with the findings of Nowsad [12], Habib [5] and Kleih et al. [6] while the findings of Ahmed et al. [13] are controversial to the present study and he reported that commission rate was as high as $10-12 \%$ in arat from fishermen in coastal belt of Bangladesh.

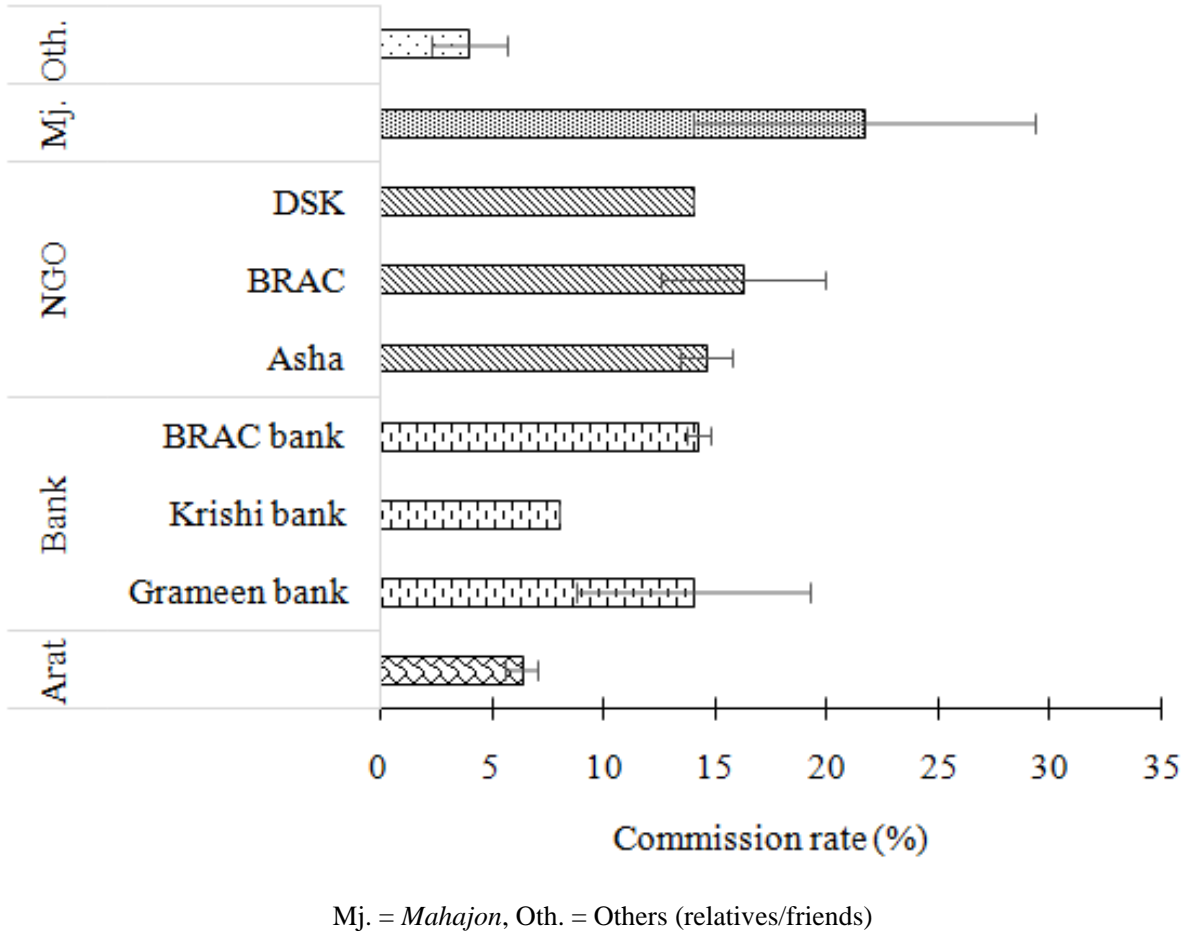

Figure 3. Commission rate of various credit agencies (\%) in Kishoreganj haor. 


\subsection{Rate of commission in arat}

Commission rate against dadon taken from DR and DnR fishermen in six fish landing centers are summarized in Table 1. The result revealed that aratder took 3\%-5\% commission from DR fishermen and 1.8\%-3\% from DnR in different FLC. Additionally, the worker in arat, often called 'Koyal' in local term, took extra 2.81\%-3.6\% commission from DR fishermen and 1.69\%-3\% from DnR fishermen. There the cumulative total commission went very high, as high as $5.9 \%$ to $8.5 \%$ in Kishoreganj haor, for the fishermen who receive dadon compared to DnR fishermen (3.9\% to 5.8\%). The reason for such high commission taken from DR fishermen was observed due to receiving dadon only. However, the rate of commission taken by the dadonders of Nikli, Rodar Podda, Chouganga and Tarail differed significantly ( $\mathrm{p}<$ 0.05) (Table 1).

Table 1. Rate of commission in arat (\%) given by dadon receiver and non-receiver fishermen

\begin{tabular}{ccccccc}
\hline \multirow{2}{*}{$\begin{array}{c}\text { Fish landing center } \\
\text { (FLC) }\end{array}$} & \multicolumn{2}{c}{ Commission } & \multicolumn{2}{c}{ Extra commission } & \multicolumn{2}{c}{ Total commission } \\
\cline { 2 - 7 } Nikli & DR & DnR & DR & DnR & DR & DnR \\
\hline Chamra ghat & $5 \pm 0^{\mathrm{b}}$ & $1.8 \pm 0.73^{\mathrm{a}}$ & $3.1 \pm 0.19^{\mathrm{a}}$ & $2.97 \pm 0.21^{\mathrm{a}}$ & $8 \pm 0.16^{\mathrm{b}}$ & $4.77 \pm 0.64^{\mathrm{a}}$ \\
Kargaon & $4.8 \pm 0.37^{\mathrm{a}}$ & $4 \pm 1^{\mathrm{a}}$ & $2.81 \pm 0.18^{\mathrm{a}}$ & $1.69 \pm 0.5^{\mathrm{a}}$ & $7.61 \pm 0.29^{\mathrm{a}}$ & $5.69 \pm 1.45^{\mathrm{a}}$ \\
Chouganga & $3 \pm 0^{\mathrm{a}}$ & $1.8 \pm 0.73^{\mathrm{a}}$ & $2.9 \pm 0.18^{\mathrm{a}}$ & $2.1 \pm 0.24^{\mathrm{a}}$ & $5.9 \pm 0.19^{\mathrm{a}}$ & $3.9 \pm 0.6^{\mathrm{a}}$ \\
Rodar podda & $3.8 \pm 0.49^{\mathrm{a}}$ & $3 \pm 0.16^{\mathrm{a}}$ & $3.6 \pm 0.4^{\mathrm{a}}$ & $2.28 \pm 0.28^{\mathrm{a}}$ & $7.4 \pm 0.6^{\mathrm{b}}$ & $5.28 \pm 0.23^{\mathrm{a}}$ \\
Tarail & $5 \pm 0^{\mathrm{b}}$ & $2.8 \pm 0.2^{\mathrm{a}}$ & $3.5 \pm 0.27^{\mathrm{a}}$ & $3 \pm 0.27^{\mathrm{a}}$ & $8.5 \pm 0.27^{\mathrm{b}}$ & $5.8 \pm 0.34^{\mathrm{a}}$ \\
\hline
\end{tabular}

$\mathrm{DR}=$ Dadon receiver, DnR = Dadon non-receiver

Mean values with different superscripts in the same row differ significantly $(\mathrm{p}<0.05)$.

\subsection{Difference of commission rate within species, size and quality of fish}

Table 2 shows that there was no difference of commission rate within the species, size and quality of fish captured by DR and DnR fishermen among 6 fish landing centers in Kishoreganj haor. Nowsad [12], working with the fish farmers and fishers of Challan Beel area in Natore and Pabna, also reported that fish were sold in primary market though an auction and aratdar got variable rates of commission depending on different amount of dadon given to the farmers and fishers.

Table 2. Difference of commission within species, size, quality of fish against taking dadon

\begin{tabular}{ccccccc}
\hline \multirow{2}{*}{ Fish landing center } & \multicolumn{9}{c}{ Difference of commission (\%) } \\
\cline { 2 - 7 } & \multicolumn{2}{c}{ Species } & \multicolumn{3}{c}{ Size } & \multicolumn{2}{c}{ Quality } \\
\cline { 2 - 7 } & DR & DnR & DR & DnR & DR & DnR \\
\hline Nikli & 0.0 & 0.0 & 0.0 & 0.0 & 0.0 & 0.0 \\
Chamra ghat & 0.0 & 0.0 & 0.0 & 0.0 & 0.0 & 0.0 \\
Korgaon & 0.0 & 0.0 & 0.0 & 0.0 & 0.0 & 0.0 \\
Chouganga & 0.0 & 0.0 & 0.0 & 0.0 & 0.0 & 0.0 \\
Rodar podda & 0.0 & 0.0 & 0.0 & 0.0 & 0.0 & 0.0 \\
Tarail & 0.0 & 0.0 & 0.0 & 0.0 & 0.0 & 0.0 \\
\hline
\end{tabular}

$\mathrm{DR}=$ Dadon receiver, $\mathrm{DnR}=$ Dadon non-receiver

\subsection{Status of dolta or dholon in Kishoreganj haor}

"Dholta" or "dholon", is meant for a kind of marketing tax paid by fishermen who took dadon from aratder, practiced in traditional marketing system during auction of fish at arat. Table 3 revealed that aratder and aratders' paid staff (koyal or cleaner) in Kishoreganj haor took 0.1-0.75 kg fish out of an average $10 \mathrm{~kg}$ fish during auction based on species and location. The commission of dholta taken from dadon receiver was higher in aratder (4.41\%) followed by koyal (3.5\%) and cleaner/water supplier $(1 \%)(\mathrm{p}<0.05)$. The cleaner or water supplier in arat took $100 \mathrm{~g}$ fish in each 10 $\mathrm{kg}$ fish from both dadon receiver and non-receiver fishermen, where commission of dholta was $1 \%$. It was crucial that 'dholta' was taken from both DR and DnR fishermen (Table 3). Nowsad [7] reported that the inhumane clutch of money lending by the dadonders or aratders, the fishers have been less-paid in the primary commission market in many 
ways, as by high rate of commission, reduced weight, dholon and also "big one fish" taken by the aratders or adatders' staff (koyal, sarker, cleaner etc.).

Table 3. Amount of dholta or dholon taken by working person in arat

\begin{tabular}{|c|c|c|c|c|c|c|}
\hline \multirow{2}{*}{ Working person in arat } & \multicolumn{3}{|c|}{ Dadon receiver } & \multicolumn{3}{|c|}{ Dadon non-receiver } \\
\hline & TQF (kg) & WFT (kg) & $\mathrm{AD}(\%)$ & TQF (kg) & WFT (kg) & $\mathrm{AD}(\%)$ \\
\hline Aratder & $10.32 \pm 1.34$ & $0.53 \pm .05$ & $4.81 \pm .39^{\mathrm{b}}$ & $22.13 \pm 5.14$ & $0.45 \pm .09$ & $2.97 \pm .36^{\mathrm{a}}$ \\
\hline Sarker & $0 \pm 0$ & $0 \pm 0$ & $0 \pm 0$ & $0 \pm 0$ & $0 \pm 0$ & $0 \pm 0$ \\
\hline Koyal & $10 \pm 0$ & $0.75 \pm .5$ & $3.5 \pm 1^{b}$ & $0 \pm 0$ & $0 \pm 0$ & $0 \pm 0^{\mathrm{a}}$ \\
\hline Cleaner/water supplier & $10 \pm 0$ & $0.1 \pm 0$ & $1 \pm 0^{\mathrm{a}}$ & $10 \pm 0$ & $0.1 \pm 0$ & $1 \pm 0^{\mathrm{a}}$ \\
\hline Others (Middle man) & $0 \pm 0$ & $0 \pm 0$ & $0 \pm 0$ & $0 \pm 0$ & $0 \pm 0$ & $0 \pm 0$ \\
\hline
\end{tabular}

$\mathrm{DR}=$ Dadon receiver, $\mathrm{DnR}=$ Dadon non-receiver, $\mathrm{TFQ}=$ Total quantity of fish, WFT $=$ Weight of fish taken, $\mathrm{AD}=$ Amount of $d$ holon. Mean values with different superscripts in same row and column differ significantly $(\mathrm{p}<0.05)$.

\subsection{Advantage of taking dadon}

Figure 4 summarizes the advantages of taking dadan from aratder as perceived from present study. Since no mortgage assets were required, the highest proportion (33\%) of fishermen took dadon from dadonder. A $24 \%$ dadon receiver claimed that they took dadon due to its easy terms and conditions, $20 \%$ took it for low interest rate, $15 \%$ for having flexibility of daily or monthly repayment and $6 \%$ for opportunity of getting any amount of dadon as per necessity. Habib [5] reported that dadon was provided on trust rather than by written document or against any collateral property due to lack of collateral assets like landed property. Many authors [5, 6, 7] observed low interest rate of dadon compared to other forms of loan, either institutional or non-institutional, which has also been well agreed in the present findings.

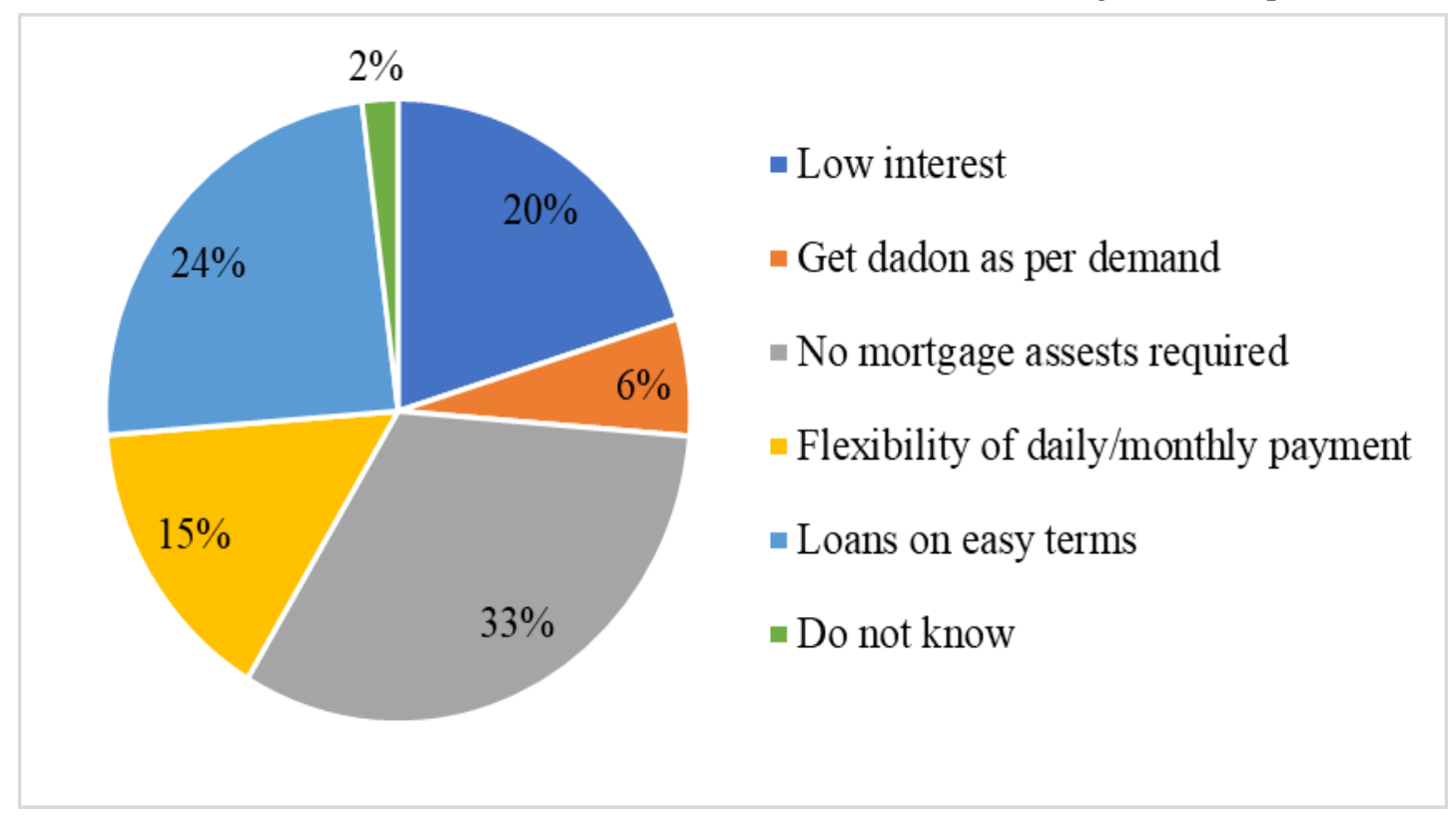

Figure 4. Advantage of taking dadon (\%).

\subsection{Purpose and utilization of dadon}

The purpose and utilization of dadon by the DR have been depicted in Figure 5 . The study revealed that dadon was taken mainly for fishing purposes (56.83\%) and household purposes (43.17\%). In fishing purposes, highest utilization of dadon money was found to be for repairing boat or trawler (23.56\%), followed by leasing haor water body (14.83\%), purchase of boat $(12.47 \%)$, purchase of net or other gears $(4.16 \%)$ and management of sanctuary in haor waters (1.81\%). In household purposes, the highest amount was used in children's education (18.97\%) followed by repair and renovating house (13.44\%), purchase of land (5.83\%) and repay of loan (2.69\%). Ali [14] and Ahmed et al. [13] observed that fishermen took dadon from different resources for maintaining their family during lean and ban fishing period as well as for purchasing fishing equipment. 


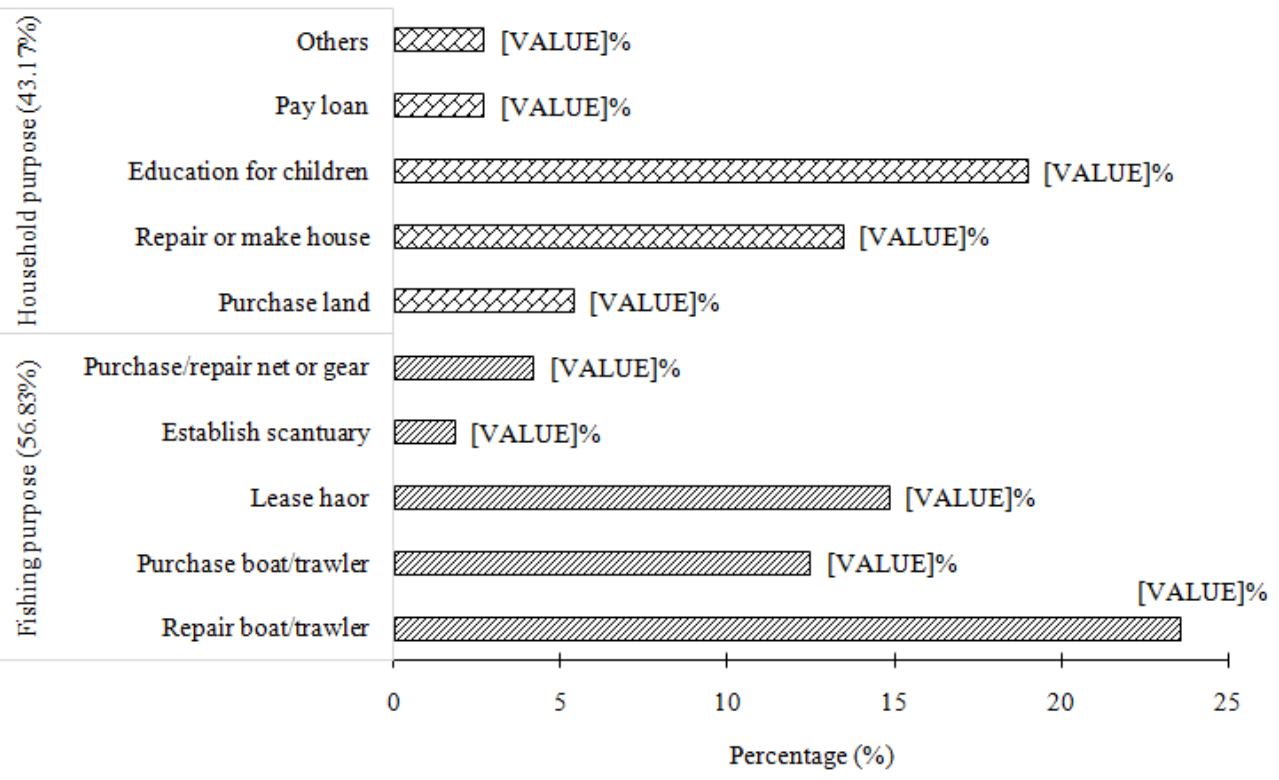

Figure 5. Reasons for taking dadon (\%) by fishermen in Kishoreganj haor.

\subsection{Mode of payment of dadon}

It was revealed that most of the DR fishermen (58\%) repaid the total amount taken by the end of the same fishing season, while monthly, weekly and daily repayment were observed to be $15 \%, 7 \%$ and $2 \%$, respectively. About $18 \%$ DR fishermen told that they could not repay the dadon, because of their inability for low income. Crow and Murshid [8] reported that most of the dadons have been repaid by the beginning of next fishing season, but not all dadons could be collected or repaid, which is also well agreed in the present findings. This may also happen if the aratder wishes to keep the fishermen under his obligation for the next season. In that case, more dadon is given to the same DR. On the contrary, it may reflect either the inability of the fishermen who receive dadon to repay the loan or the willingness of the aratder to fund or support for some of the other activities of the fishermen to expand control. Ferdoushi and Xiang-guo [15] reported that the payment was found to be 50\% immediate (dadon) and 50\% within 1 to 7 days of selling in mud crab trading, from fattener to local agent, in the southwest region of the country, Shatkhira and Shamnagar.

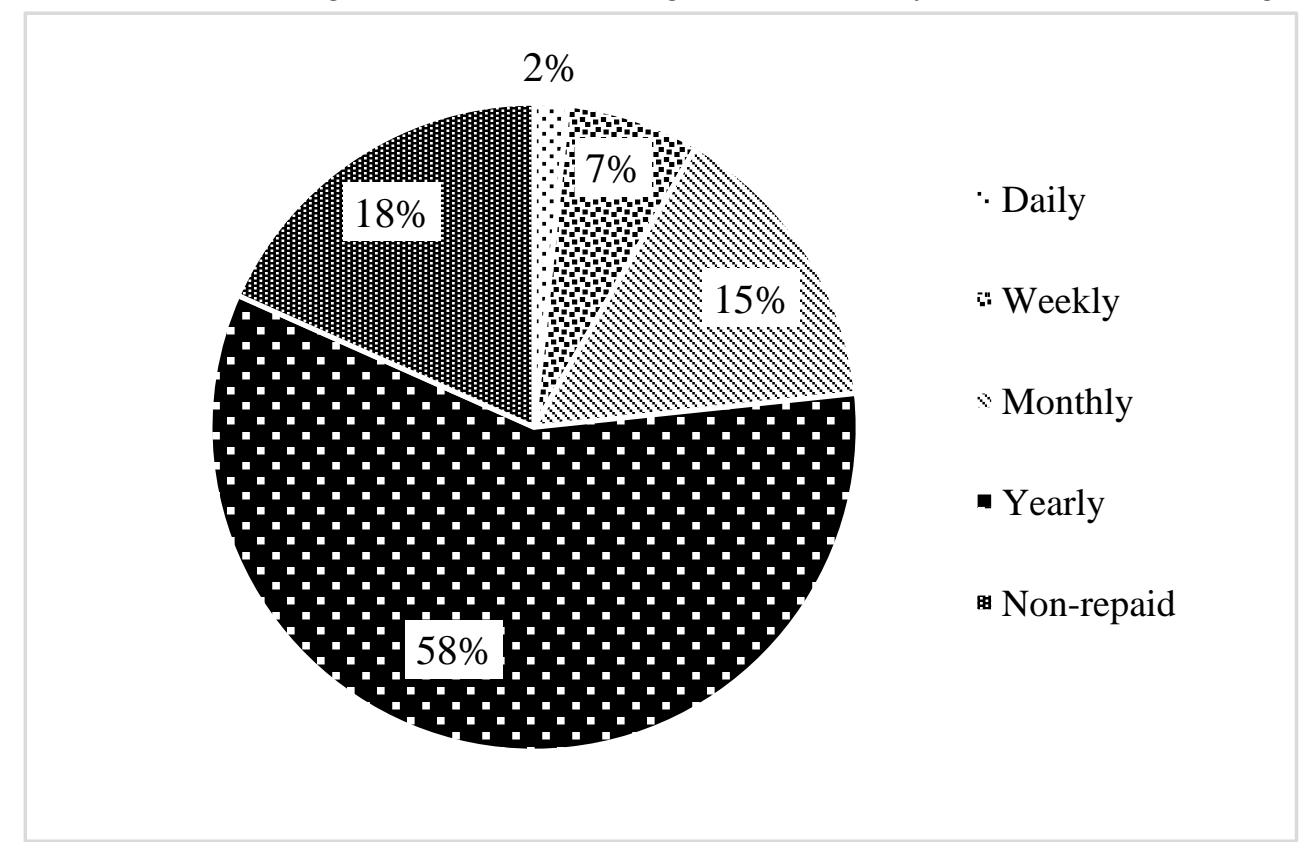

Figure 6. Repayment status of dadon (\%). 


\subsection{Financial profiles of dadon receiver (DR) and dadon non-receiver (DnR) fishermen}

Monthly average income and annual savings of DR and DnR fishermen are shown in Table 4. Results revealed that the monthly income and annual savings were comparatively higher in most cases in DR fishermen than DnR fishermen ( $>0.05$ ). The monthly average income level of DR fishermen ranged from 10,900-17,000 BDT, while that of DnR fishermen ranged from 10,200-15,000 BDT. In addition, the annual savings of DR fishermen ranged from 14,600-37,000 BDT and DnR fishermen ranged from 14,600-32,200 BDT. These higher income and savings of DR fishermen might be due to higher fishing activity and increased economic mobility, geared by the pressure of paying back higher interest for dadon taken and for the urge of improved family maintenance. The fishermen who took dadon were bound to the aratder, who is also money lender, in a debt cycle and must sell all the fish they harvest through the aratder in a price much lesser than the market price $[12,25]$. So, DRs were found to perform well in earning and saving money compared to DnRs.

Table 4. Average income (monthly) and savings (annual) of DR and DnR fishermen (In thousand BDT)

\begin{tabular}{ccccc}
\hline \multirow{2}{*}{ Fish landing center } & \multicolumn{2}{c}{ Monthly income (BDT) $^{2}$ Annual savings (BDT) } \\
\cline { 2 - 5 } & DR & DnR & DR & $16.4 \pm 4.03^{\mathrm{a}}$ \\
\hline Nikli & $13.1 \pm 1.7^{\mathrm{b}}$ & $14.5 \pm 2.39^{\mathrm{b}}$ & $16.6 \pm 4.68^{\mathrm{a}}$ & $19.2 \pm 11.79^{\mathrm{a}}$ \\
Chamra ghat & $17.3 \pm 2.69^{\mathrm{b}}$ & $13.7 \pm 3.07^{\mathrm{a}}$ & $37.2 .1 \pm 6.39^{\mathrm{b}}$ & $22.1 \pm 7.55^{\mathrm{a}}$ \\
Kargaon & $13.1 \pm 1.95^{\mathrm{b}}$ & $14.7 \pm 2.86^{\mathrm{b}}$ & $23.6 \pm 5.18^{\mathrm{a}}$ & $24.8 \pm 7.26^{\mathrm{a}}$ \\
Chouganga & $15 \pm 2.68^{\mathrm{b}}$ & $11.1 \pm .71^{\mathrm{a}}$ & $33.2 \pm 10.23^{\mathrm{b}}$ & $14.6 \pm 3.34^{\mathrm{a}}$ \\
Rodar podda & $10.9 \pm 1.57^{\mathrm{a}}$ & $10.2 \pm 1.46^{\mathrm{a}}$ & $17.2 \pm 3.61^{\mathrm{b}}$ & $22.1 \pm 6.16^{\mathrm{a}}$ \\
Tarail & $14.8 \pm 3.5^{\mathrm{a}}$ & $14.2 \pm 1.43^{\mathrm{a}}$ & $26.4 \pm 3.71^{\mathrm{b}}$ & \\
\hline
\end{tabular}

Mean \pm SD values for same parameter with different superscripts in the same row differ significantly $(\mathrm{p}<0.05)$.

\subsection{Social status of $D R$ and DnR fishermen based on monthly income}

Average income level of an individual fishing family determines its social status in the society. The social status of DR and DnR fishermen were explained under three (3) categories by their monthly income such as poor (below 10,000 BDT), middle class (10,000-20,000 BDT) and rich (above 20,000) (Figure 7). Results revealed that the social status of DR fishermen was comparatively better than DnR fishermen ( $p>0.05$ ) because of their comparatively higher average income level. Middle class group were dominant in two fishery association groups but higher in DR fishermen (60\%) compared to DnR fishermen (53.3\%).

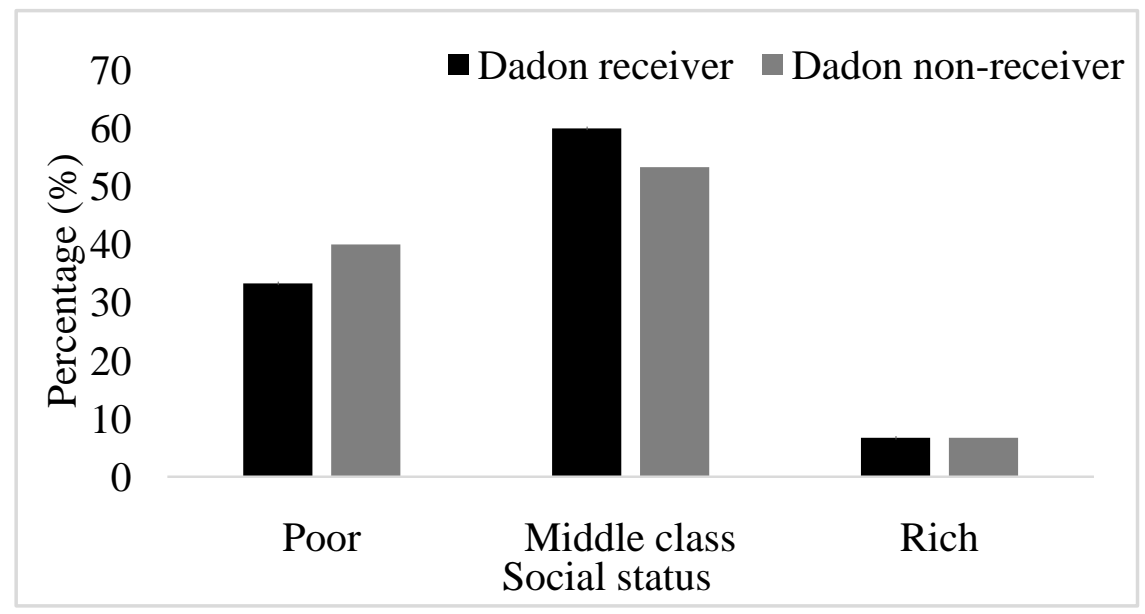

Figure 7. Social status (\%) of dadon receiver and non-receiver fishermen.

\subsection{Demographic profiles of DR and DnR fishers' household}

The demographic characteristics are summarized in Table 5. It was found that young aged members (11-30 years) were dominant in both the fishers' household but higher in DR household. This demographic feature of fishing communities agreed well with the overall all demographic characteristics of the country [16]. Ali et al. [17] observed that young and middle age persons in the range of 20-40 years was the highest (58\%) and above 50 years was the lowest (20\%) in fishing community of Tarakanda upazila in Mymensingh district which was much similar to the present study. 
Results revealed that medium size family was dominant in both fishers' association but higher in DnR fishers' household ( $\mathrm{p}>0.05$ ). The educational status was comparatively better in DR fishermen than DnR fishermen ( $>0.05)$. This variation might be due to economic non-wellbeing and lack of awareness about education, which support the findings of Sufian et al. [18] conducted with the fishing communities of Dekar haor in Sunamganj.

Table 5. Profile of household members' in DR and DnR fishermen

\begin{tabular}{|c|c|c|c|c|c|}
\hline \multirow{2}{*}{ Variables } & \multicolumn{2}{|c|}{ Percentage } & \multirow{2}{*}{ Variables } & \multicolumn{2}{|c|}{ Percentage } \\
\hline & DR & DnR & & DR & DnR \\
\hline \multicolumn{3}{|c|}{ Age Structure (years) } & \multicolumn{3}{|c|}{ Family size } \\
\hline Children (0-10) & $21.21^{\mathrm{a}}$ & $31.99^{\mathrm{a}}$ & Small (2-4) & $37.36^{\mathrm{a}}$ & $25.74^{\mathrm{a}}$ \\
\hline Young (11-30) & $45.26^{\mathrm{a}}$ & $43.9^{\mathrm{a}}$ & Medium (5-8) & $51.67^{\mathrm{a}}$ & $72.41^{\mathrm{a}}$ \\
\hline Middle (31-50) & $24.49^{\mathrm{a}}$ & $15.5^{\mathrm{a}}$ & Large (above 8) & $10.97^{\mathrm{a}}$ & $1.85^{\mathrm{a}}$ \\
\hline Old $(>50)$ & $9.04^{\mathrm{a}}$ & $8.62^{\mathrm{a}}$ & \multicolumn{3}{|c|}{ Educational status } \\
\hline \multicolumn{3}{|c|}{ Secondary occupational status } & Illiterate & $32.91^{\mathrm{a}}$ & $32.14^{\mathrm{a}}$ \\
\hline Agriculture & $28.58^{\mathrm{a}}$ & $30.14^{\mathrm{a}}$ & Primary education & $34.24^{\mathrm{a}}$ & $33.39^{\mathrm{a}}$ \\
\hline Business & 1.47 & 0 & SSC & $23.62^{\mathrm{a}}$ & $26.86^{\mathrm{a}}$ \\
\hline Day labour & $1.47^{\mathrm{a}}$ & $2.17^{\mathrm{a}}$ & HSC & $3.37^{\mathrm{a}}$ & $2.01^{\mathrm{a}}$ \\
\hline Agri.+Busi. & $1.85^{\mathrm{a}}$ & $1.96^{\mathrm{a}}$ & Graduate & $0.58^{\mathrm{a}}$ & $0.88^{\mathrm{a}}$ \\
\hline Agri.+ DL & $9.51^{\mathrm{a}}$ & $8.9^{\mathrm{a}}$ & Madrasah & $5.28^{\mathrm{a}}$ & $4.72^{\mathrm{a}}$ \\
\hline
\end{tabular}

$\mathrm{DR}=$ Dadon receiver, $\mathrm{DnR}=$ Dadon non-receiver, Agri. $=$ Agriculture, Busi. $=$ Business, $\mathrm{DL}=$ Day labour, $\mathrm{SSC}=$ Secondary school certificate

HSC = Higher secondary certificate.

Values with different superscripts within same parameter in the same row differ significantly $(\mathrm{p}<0.05)$.

\subsection{Physical assets of $D R$ and DnR fishermen}

As far as the estimation of ownership of land and homestead area was considered, 1 to 5 decimal land and 1 to 3 decimal homestead area were dominant in both fishing groups but comparatively higher in DR fishermen than DnR fishermen. Results revealed that 4 to 8 decimal homestead area possessed significantly higher $(\mathrm{p}<0.05)$ by DnR $(43.8 \%)$ fishermen compared to DR fishermen (21.87\%).

Present study observed all fishermen from both DR and DnR households (100\%) used tube-wells water for drinking. This scenario was quite common among the fishermen in most areas of Bangladesh and similar results were documented by Alam and Bashar [19] about 30 years before. According to BBS [20], about 98\% people from seven geographic divisions of Bangladesh used to drink tube-well water which supports this study.

The electricity facility was higher in DR fishermen (93.75\%) compared to DnR fishermen (91.48\%), which was much higher than the findings by Trina et al. [21] in Dekhar haor, Sunamganj 5 year back, where about $76 \%$ fishermen had access to electricity. The economic condition of stakeholders was the main cause for decreasing the access of electricity facilities between two fishery association groups.

The majority of the fishermen both in DR and DnR had kacha house, but higher number in DnR fishermen (96.3\%) compared to DR fishermen (93.34\%). This might be due to the dadon receiver fishermen used a portion of dadon for household renovation including construction of new house. Sufian et al. [18] reported that $90 \%$ fishermen were living in kacha house which support the present study.

Kabir [22] and Khair [11] reported that 60\% fishermen were found to have small non-mechanized boats and fishing net which was in agreement with the present study. It was found from the survey that most of the DR fishermen had their own fishing boat and net (51.35\%) compared to DnR fishermen (38.89\%). As observed, the fishermen took dadon from aratder for the preparations of next season fishing, mending or purchase of nets and other gears, as well as for family subsistence during fishing period. These findings are in agreement with that of Habib [5].

However, in spite of their comparative economic wellbeing as observed during the present survey, most of the DR fishermen (63.9\%) told that their livelihood status became worse compared to the past, due to taking dadon. On the other hand, 52.5\% DnR fishermen said that their livelihood status had been improved compared to past, because of not taking dadon (Table 6). However, considering all parameters in Table 6, it was observed that the livelihood improvement status was comparatively better in DR fishermen ( $>>0.05$ ) compared to DnR fishermen. 
Table 6. Profile of physical assets of dadon receiver (DR) and non-receiver (DnR) fishers' household

\begin{tabular}{|c|c|c|c|c|c|}
\hline \multirow{2}{*}{ Variables } & \multicolumn{2}{|c|}{ Percentage } & \multirow{2}{*}{ Variables } & \multicolumn{2}{|c|}{ Percentage } \\
\hline & DR & DnR & & DR & DnR \\
\hline \multicolumn{3}{|c|}{ Land ownership } & \multicolumn{3}{|c|}{ Source of drinking water } \\
\hline Landless & $3.34^{\mathrm{a}}$ & $7.5^{\mathrm{a}}$ & Pond/river/canal & 0 & 0 \\
\hline 1 to 5 & $55.7^{\mathrm{a}}$ & $48.5^{\mathrm{a}}$ & Rain & 0 & 0 \\
\hline 6 to 50 & $23.2^{\mathrm{a}}$ & $36.8^{\mathrm{a}}$ & Supply & $100^{\mathrm{a}}$ & $100^{\mathrm{a}}$ \\
\hline Above 50 & $17.8^{\mathrm{a}}$ & $7.5^{\mathrm{a}}$ & Tube-well & 0 & 0 \\
\hline \multicolumn{3}{|c|}{ Access to homestead area } & \multicolumn{3}{|c|}{ Ownership of fishing assets } \\
\hline No land & $3.33^{\mathrm{a}}$ & $7.5^{\mathrm{a}}$ & Boat & $14.2^{\mathrm{a}}$ & $5.5^{\mathrm{a}}$ \\
\hline$<1$ & 3.33 & 0 & Net & $7.5^{\mathrm{a}}$ & $13.8^{\mathrm{a}}$ \\
\hline 1 to 3 & $56.7^{\mathrm{a}}$ & $36.8^{\mathrm{a}}$ & Both & $51.3^{\mathrm{a}}$ & $38.9^{\circ}$ \\
\hline 4 to 8 & $21.7^{\mathrm{b}}$ & $43.8^{\mathrm{a}}$ & Hired boat & $7.5^{\mathrm{a}}$ & $11.1^{\mathrm{a}}$ \\
\hline 8 to 12 & $11.7^{\mathrm{a}}$ & $6.7^{\mathrm{a}}$ & Hired Net & $14.2^{\mathrm{a}}$ & $8.3^{\mathrm{a}}$ \\
\hline Above 12 & $3.33^{\mathrm{a}}$ & $5.2^{\mathrm{a}}$ & Hired both & $5.1^{\mathrm{a}}$ & $22.2^{\circ}$ \\
\hline \multicolumn{3}{|c|}{ Housing condition } & \multicolumn{3}{|c|}{ Kitchen facilities } \\
\hline Kacha & $93.3^{\mathrm{a}}$ & $96.3^{\mathrm{a}}$ & Opened & $26.4^{\mathrm{a}}$ & $28.2^{\mathrm{a}}$ \\
\hline Semi-pacca & $4.67^{\mathrm{a}}$ & $3.7^{\mathrm{a}}$ & OFR & $8.33^{b}$ & $15.2^{\circ}$ \\
\hline Pacca & 1.99 & 0 & FWR & $65.2^{b}$ & $56.7^{\circ}$ \\
\hline \multicolumn{3}{|c|}{ Electricity facilities } & \multicolumn{3}{|c|}{ Sanitation facilities } \\
\hline No electricity & 0 & 3.33 & Sanitary & $73.7^{\mathrm{a}}$ & $52.5^{\circ}$ \\
\hline Solar & $6.25^{\mathrm{a}}$ & $5.2^{\mathrm{a}}$ & Closed & $19.5^{\mathrm{a}}$ & $34.0^{\circ}$ \\
\hline \multirow[t]{2}{*}{ Electricity } & $93.7^{\mathrm{a}}$ & $91.5^{\mathrm{a}}$ & Opened & $6.6^{\mathrm{a}}$ & $13.3^{\mathrm{a}}$ \\
\hline & & & \multicolumn{3}{|c|}{ Livelihood improvement status } \\
\hline \multirow[t]{2}{*}{ Both } & 0 & 0 & Improved & $36.1^{\mathrm{a}}$ & $52.5^{\circ}$ \\
\hline & & & Not-improved & $63.9^{\mathrm{a}}$ & $20.2^{\circ}$ \\
\hline
\end{tabular}

$\mathrm{DR}=$ Dadon receiver, DnR = Dadon non-receiver, OFR = Only fence no roof, FWR = Fence with roof

Values with different superscripts within same parameter in the same row differ significantly $(p<0.05)$.

\subsection{Empowerment indicators of women in DR and DnR fisher's household}

The four indicators such as mobility, economic security, ability to make small purchases and involvement in major household decisions were used to find out the women's empowerment in dadon receiver and non-receiver fisher's households (Table 7).

Mixed results were obtained from the women of two groups. In case of mobility and decision taking for small purchase, women from DnR fishermen were better empowered $(\mathrm{p}<0.05)$ than those from DR fishermen. While in case of economic security and family decision making on children education, treatment and marriage, women from DR were better empowered compared to women from DnRs $(\mathrm{P}<0.05)$. According to Kazal et al. [23], a very high percentage (72\%) of households reported that women had active role in household decision-making jointly with their husbands. Present findings also gave evidence that fishers women were empowered in household decision-making in haor areas, which agree with the findings of other studies. Kazal et al. [23] observed 38\% women from fishery community households took decision jointly with their husbands, while $21 \%$ of them took household decision independently during any family food crisis. CDSP [24] reported that fisher-women took most of the decisions jointly with their husbands, which also have been confirmed by the present study. 
Table 7. Empowerment indicators of women in DR and DnR fisher's household

\begin{tabular}{|c|c|c|c|c|c|c|}
\hline \multirow{2}{*}{ Variables } & \multicolumn{2}{|c|}{ Percentage } & \multirow{2}{*}{\multicolumn{2}{|c|}{ Variables }} & \multicolumn{2}{|c|}{ Percentage } \\
\hline & DR & DnR & & & DR & DnR \\
\hline \multicolumn{3}{|c|}{ Women's mobility } & \multicolumn{4}{|c|}{ Purchase of small things } \\
\hline Show doctor & $21.6^{\mathrm{a}}$ & $21.3^{\mathrm{a}}$ & \multicolumn{2}{|l|}{ Own dress } & $9.5^{\mathrm{a}}$ & $13.9^{b}$ \\
\hline Visit relatives' house & $2.1^{\mathrm{a}}$ & $18.5^{b}$ & \multicolumn{2}{|l|}{ Own cosmetics } & $2.1^{\mathrm{a}}$ & $5.5^{b}$ \\
\hline Buy medicine & $14.1^{\mathrm{a}}$ & $17.2^{b}$ & \multicolumn{4}{|c|}{ Involvement in major decision about children } \\
\hline \multicolumn{3}{|c|}{ Economic security } & \multirow{2}{*}{ Education } & Ind. & $38.6^{b}$ & $34.2^{\mathrm{a}}$ \\
\hline Mobile & $9.7^{\mathrm{b}}$ & $6.6^{\mathrm{a}}$ & & $\mathrm{JwHb}$ & $38.6^{\mathrm{b}}$ & $30.9^{\mathrm{a}}$ \\
\hline b-kash account & 0 & 0 & \multirow{2}{*}{ Treatment } & Ind. & $36.5^{b}$ & $32.2^{\mathrm{a}}$ \\
\hline Bank account & $4.2^{\mathrm{b}}$ & $1.8^{\mathrm{a}}$ & & $\mathrm{JwHb}$ & $36.5^{b}$ & $28.8^{\mathrm{a}}$ \\
\hline Loan from NGO & $12.9^{\mathrm{a}}$ & $26.5^{b}$ & \multirow{2}{*}{ Marriage } & Ind. & $37.5^{\mathrm{b}}$ & $25.1^{\mathrm{a}}$ \\
\hline Land & $12.2^{b}$ & $3.3^{\mathrm{a}}$ & & $\mathrm{JwHb}$ & $37.5^{\mathrm{b}}$ & $25.1^{\mathrm{a}}$ \\
\hline
\end{tabular}

$\mathrm{DR}=$ Dadon receiver, $\mathrm{DnR}=$ Dadon non-receiver, Ind. = Individual, $\mathrm{JwHb}=$ Jointly with husband, Values with different superscripts within same parameter in the same row differ significantly $(\mathrm{p}<0.05)$.

\section{Conclusion}

In general, dadon system in the fishing communities has furnished the traditional kinship arrangement, but confines the economic freedom of fishers by binding them into long-term exploitative debt bondage. However, the effective utilization of this social capital system can play an important role in reducing vulnerability and help people to survive in times of crisis. Dadon was found to be a major source of livelihood among the fishers' communities in Kishoreganj haor areas and played a positive role to lead better life by dadon receiver fishermen compared to dadon non-receiver fishermen. The present study would serve as a useful reference of dadon system in future fisheries management. Since the rate of commission against dadon is very high, many present dadon receivers were not interested to receive dadon anymore. By reducing commission rate to around $2 \%-3 \%$ through implementing rules, regulations and strict monitoring and surveillance by the GO and NGOs, dadon system can further aid in sustainable capture fisheries management, especially in floodplain fisheries.

\section{Acknowledgements}

The authors gratefully acknowledge Krishi Gobeshona Foundation (KGF) for funding this research. Thanks are due to the fishing communities in Kishoreganj haor areas for their supports and collaborations during the study.

\section{Conflict of interest}

The authors declare no conflict of interest.

\section{References}

[1] Habib, I. (1964). Usury in medieval India. Comparative Studies in Society and History, 6(4): 393-419.

[2] Bhattacharya, S. (1982). Regional Economy (1757-1857): Eastern India, Kumar, D. (Ed.), The Cambridge Economic History of India, 2: 270-332.

[3] Raychaudhuri, T. (1982). Non-Agricultural Production: Mughal India. The Cambridge Economic History of India, 1: $261-307$.

[4] BBS (Bangladesh Bureau of Statistics). (2014). Rural Credit Survey, 2014, Statistics and Informatics Division, Ministry of Planning, Bangladesh. P. 4.

[5] Habib, A. (2001). Delipara: an obscure fishing village of Bangladesh. Community Development Centre, Chittagong, Bangladesh.

[6] Kleih, U., Alam, K., Dastidar, R., Dutta, U., Oudwater, N., and Ward A. (2003). Livelihoods in coastal fishing communities, and the marine fish marketing system of Bangladesh. National Resources Institute (NRI), Greenwich University, London, NRI 2712, p. 81.

[7] Nowsad, A. K. M. A. (2013). Post-harvest fisheries management- The Final Report submitted to the Supply Chain Development Component (SCDC) of NATP, Hortex Foundation, p. 76.

[8] Crow, B. and Murshid, K. A. S. (1992). The finance of trade and agriculture in a backward area of Bangladesh. The European 
Journal of Development Research, 4(2): 36-60.

[9] Islam, M. M., Islam, N., Sunny, A. R., Jentoft, S., Ullah, M. H., and Sharifuzzaman, S. M. (2016). Fishers' perceptions of the performance of hilsa shad (Tenualosa ilisha) sanctuaries in Bangladesh. Ocean \& Coastal Management, 130: 309-316.

[10] Chowdhury, A. J. (2012). Investigation on livelihood status of hilsa fishing communities in Lakshmipur district. M.Sc. Thesis, Department of Fisheries Management, Bangladesh Agricultural University, Mymensingh.

[11] Khair, M. A. (2005). Study on the livelihood strategies of Parkibazar Fisher community, Anwara, Chittagong. M.Sc. Thesis, Institute of Marine Sciences \& Fisheries, University of Chittagong, Bangladesh.

[12] Nowsad, A. K. M. A. (2010). Post-harvest loss reduction in fisheries in Bangladesh: a way forward to food security. Final report PR, 5(8): 171.

[13] Ahmed, M., Islam, M. N., and Shamsuddoha, M. (2007). Value chain analysis in the dry fish production and marketing of post-harvest fishery products (PHFP) in the Coastal Belt of Bangladesh. Journal of Bangladesh Fisheries Research Forum, pp. 87-112.

[14] Ali, M. L. (2014). Fishers' access to fisheries resources under different management systems and their livelihood issues. Recent Advances in Fisheries of Bangladesh, 1: 161-180.

[15] Ferdoushi, Z. and Xiang-guo, Z. (2010). Mud crab (Scylla serrata) fattening in Bangladesh: present status and future prospects. Recent Advances in Fisheries of Bangladesh, 1: 191-202.

[16] BBS (Bangladesh Bureau of Statistics). (2017). Preliminary Report on the Household Income and Expenditure Survey (HIES), 2016, Dhaka: Planning Division, Government of the People’s Republic of Bangladesh. P. 48.

[17] Ali, H., Azad, M. A. K., Anisuzzaman, M., Chowdhury, M. M. R., Hoque, M., and Sharful, M. I. (2009). Livelihood status of the fish farmers in some selected areas of Tarakanda upazila of Mymensingh district. Journal of Agroforestry and Environment, 3(2): 85-89.

[18] Sufian, M. A., Kunda, M., Islam, M. J., Haque, A. T. U., and Pandit, D. (2017). Socio-economic conditions of fishermen of dekar haor in Sunamganj. Journal of Sylhet Agricultural University, 4(1): 101-109.

[19] Alam, M. F. and Bashar, M. A. (1995). Structure of cost and profitability of small scale riverine fishing in Bangladesh. Journal of Research Progress, 9: 235-241.

[20] BBS (Bangladesh Bureau of Statistics). (2019). Bangladesh Sample Vital Statistics 2018, Statistics and Informatics Division, Ministry of Planning, Bangladesh, p. 155.

[21] Trina, B. D., Roy, N. C., Das, S. K., and Ferdausi, H. J. (2015). Socio-economic status of fishers' community at Dekhar haor in Sunamganj district of Bangladesh. Journal of the Sylhet Agricultural University, 2(2): 239-24.

[22] Kabir, M. A. (2007). Study on the livelihood strategies of Monoharkhali Fisher community, Patharghata, Chittagong, M.Sc. Thesis, Institute of Marine Sciences and Fisheries, University of Chittagong, Bangladesh.

[23] Kazal, M. M. H., Villinueva, C. C., Hossain, M. Z. and Das, T. K. (2010). Food security strategies of the people living in haor areas: status and prospects. American International University, Dhaka, Bangladesh. NFPCSP Final Report, National Food Policy Capacity Strengthening Program, Ministry of Food, Dhaka.

[24] CDSP. (2012). Baseline survey 2011 (Technical report No. 1), Char Development and Settlement Project, Phase IV, Bangladesh, p. 60.

[25] Islam, M. M. (2011). Living on the margin: the poverty-vulnerability nexus in the small-scale fisheries of Bangladesh. In Poverty mosaics: Realities and prospects in small-scale fisheries, Springer, Dordrecht, pp. 71-95. 